\title{
Production of Sweet Corn on Sand Pit Soil Using Phosphate Solubizing Bacteria and Weed Bokhasi
}

\author{
Cecep Hidayat ${ }^{1}$, Sutio Agusti ${ }^{2}$, Sofiya Hasani ${ }^{3}$ \\ \{cephidayat62@uinsgd.ac.id ${ }^{1}$ \} \\ Dept Agrotechnology, UIN Sunan Gunung Djati Bandung ${ }^{1}$
}

\begin{abstract}
Sand pit soil which poor physical, chemical, and biology soil properties can be used for planting media of horticulture crops through adding beneficial microbe and organic matter. The aim of the research was to know the effect of Phosphate Solubizing Bacteria and Bokhasi on growth and yield Sweet Corn at sand pit soil. A field trial at $750 \mathrm{~m}$ above sea level had been carried out from Juni to October 2018 using randomized block design two factors with factorial pattern and three replications. The first factor was Phosphate Solubizing Bacteria $\left(0 \mathrm{ml}, 20 \mathrm{ml}\right.$ polybag ${ }^{-1}, 25 \mathrm{ml} \mathrm{polybag}^{-1}$, $30 \mathrm{ml}$ polybag $^{-1}$, while the second factor was bokhasi type (Tithonia diversifolia, Imperata cylindrica, and Eichornia crassipes). The results showed that Phosphate Solubizing Bacteria and bokhasi had interaction effect on harvest index, Phosphate Solubizing Bacteria and bokhasi had main effect on crop height, dry and wet corn cob with out corn straw, and bokhasi had main effect shoot root rasio. So application of weed bokhasi of T. Diversifolia and I. cylindrica can be used to promote corn crop growth and crop yield. While application PSB dosage $25 \mathrm{ml} \mathrm{polybag}^{-1}$ increase growth and yield of the corn crop
\end{abstract}

Keywords: Bokhasi, Phosphate solubizing bacteria, Production, Sand pit soil, Sweet corn.

\section{Introduction}

The change of land function from agriculture to non agriculture occurs in various regions of Indonesia, both at the low land, medium land, and mountains. This phenomenon threatens food production of Indonesian people because many soil that switch function is productive soil as happened in the area of Karawang and Bekasi districts. Productive rice fields are transformed into toll roads, factories, and housing. Likewise in the mountainous like main tourist destination Puncak and Lembang in Jawa island area the hotel, the restaurant, and the amusement arena utilize the productive farmland. Agricultural activities are pressed from the fertile soil and require the use of marginalized soils with low support.

One of the marginal soil that can be used for plant cultivation purposes is the sand pit. Sand mining is widely done in various Indonesia provinces to meet the needs of building materials and roads. These mining activities, though including those not economically valuable, are the source of local government revenues.

The main problem of sand pit is the low level of physical, chemical, and biological fertility. This is because in the process of mining carried out stripping soil to get the sand minerals and often leave large holes that are prone to erosion and lower the quality of the 
environment. The utilization sand pit for crop production media thus has dual function as a tool for crop production and solve the problem of decline in environmental quality.

The data of sand pit from Sumedang district is dominated by sand (75\%), Low C-organic ( 0,35\%), low P-available ( 15,19 ppm), pH 6,85 (neutral)[1]. The similar data from sand pit area in Bandung Barat, where the sand dominates $(61 \%)$, Low C-organic $(0,89 \%), \mathrm{pH}$ slightly alkalis $(7,9)$, low P-available (14 ppm) [2]. Based on data from two locations of the sand pit area in west Jawa province, indicate that using it for crop cultivation purposes, it requires the application of organic matter as a first step because for optimum plant growth requires organic material content of 3-5\% [3]. Organic matter is entry point for soil fertility improvement. Organic matter amendments inluences on soil physical properties like decreased bulk density [4], increased aggregate stability, water holding capacity, water infiltration rate and some measures of biological activity [5], improved soil water availability [6]. Organic matter is a source of nutrients and affects the population dynamics and microbia soil. For this research used weed contained in sand pit and reservoir area.

Other input provided to improve sand pit is beneficial microbes. In this case it is a phosphate solubizing bacteria (PSB) that can live in the $\mathrm{pH}$ range neutral until the alkalis in accordance with the $\mathrm{pH}$ of sand pit. PSB inoculation is also intended to use of the P total that there are plenty in tne sand pit. PSB is the most effective plant assistant to supply phosphorus at a favourable level [7] throught $\mathrm{P}$ solubilization by producing organic acids [8]. PSB is important in increasing the $\mathrm{P}$ efficiency of $\mathrm{P}$ and improving the growth and yield various crops [9].

The aim of the research was to know the effect of Phosphate Solubizing Bacteria and weed bokhasi on production of sweet corn.

\section{Method}

The materials used were sand pit from Kabupaten Bandung Barat West Java Province Soil : (S 07²5.532', E 108 06.083') $742 \mathrm{~m}$ above sea level, seed sweet corn var Bonanza F1, PSB (Pseudomonas cepacea) colection of Unpad Soil Biology laboratory, cow manure, Tithonia diversifolia, Imperata cylindrica, Eichornia crassipes. A polybag-trial was carried out at Nagreg subdistrict, West Java, Indonesia Indonesia (S=702'18, 13207', E= 107054'49,001'’) $750 \mathrm{~m}$ above sea level from June to October 2018, using Randomized Block Design with two factors and three replications.

The first factor was Phosphate Solubizing Bacteria dosage:

bo $=$ control,

b1 $=20 \mathrm{ml} \mathrm{polybag}^{-1}$

b2 $=25 \mathrm{ml} \mathrm{polybag}^{-1}$

b3 $=30 \mathrm{ml} \mathrm{polybag}^{-1}$

The second factor was type of bokhasi :

po $=$ control

$\mathrm{p} 1=$ Tithonia diversifolia $\left(280 \mathrm{~g}_{\text {polybag }}{ }^{-1}\right)$

p2 = Imperata cylindrica $\left(280 \mathrm{~g}\right.$ polybag $\left.^{-1}\right)$

p3 = Eichornia crassipes $\left(280\right.$ g polybag $\left.^{-1}\right)$ 
Parameters evaluated were crop height and shoot root rasio which were measured at last vegetative phase, harvest index and dry corn cob with and with out out corn husk were measured at harvest. The data analisys used F test at $5 \%$ level and continued with Duncan Multi Range Test at $5 \%$ level.

Sand pit soil from Bandung Barat district (S 07²5.532', E 108 06.083') were colected and analysed its texture, bulk density, porosity, soil permeability, P-total, and C-organic before using as plant growth media. Then sieved so that rocks and soil can be separated, and $28 \mathrm{~kg}$ soil inserted into $40 \mathrm{~cm}$ x 60 polybgas two weeks before planting. Next up was the making of bokhasi used Tithonia diversifolia, Imperata cylindrica, Eichornia crassipes as raw materials from Juni to July 2018 untill the compost is formed with the characteristics has a distinctive smell, color, texture that has resembled soil, loss the weight reaches $60 \%$, and temperature stable. These bokhasi (280 $\mathrm{g} \mathrm{polibag}^{-1}$ each) were mixed with soil media. Two seeds corn were planted $3 \mathrm{~cm}$ deep in the polybag ${ }^{-1}$ in the morning and directly watered. Crops were watered twice a day, but it was a day when the planting medium is quite moist. Continued fertilization was given at 7 Days After Planting (DAP), 28 DAP, and 50 DAP. Weeding by hand, pest and disease control was done by mechanical method and pesticide, and was harvest at 100 DAP wich marked with the leaves of corn have dried, yellowish, and there was a black mark on the base of the place of the seed in the cob.

\section{Result and Discussion}

\section{Crop Height}

Application of PSB and bokhasi type showed no interaction effect on crop height. There was main effect of PSB on crop height (Figure 1) and main effect of bokhasi on crop height (Figure 2)

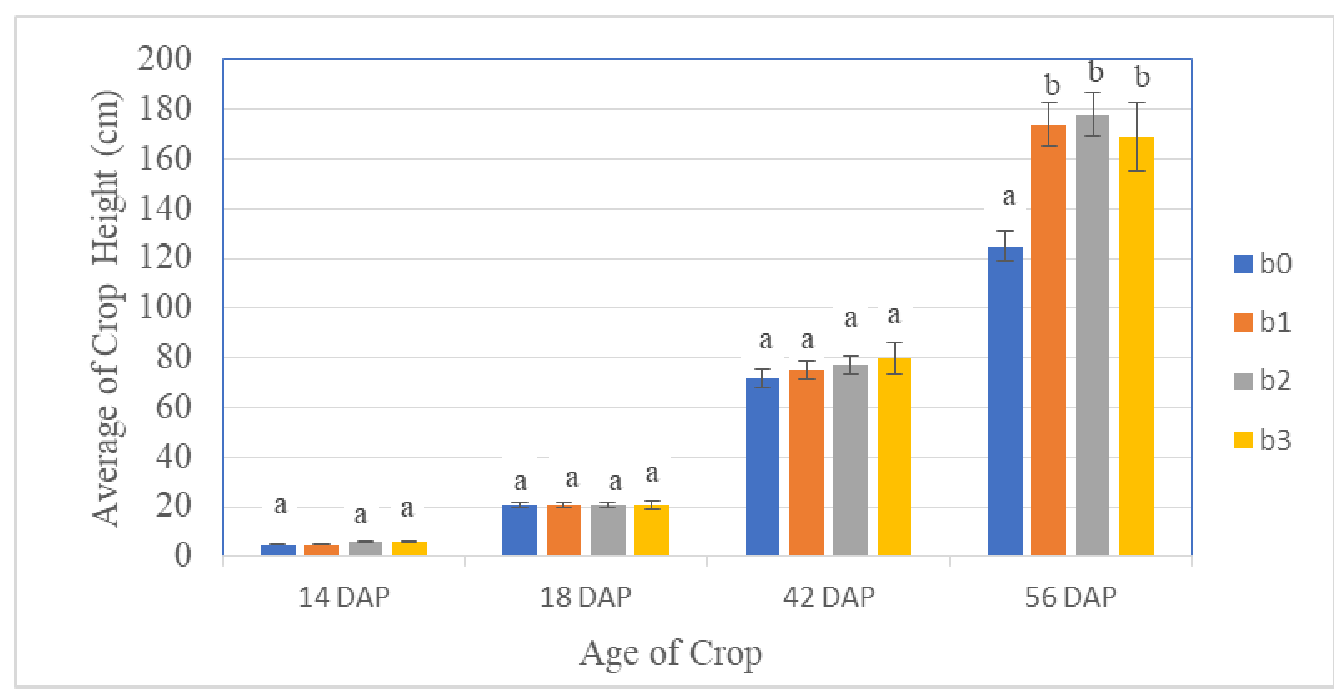

Figure 1. The Effect of PSB on Average of Crop Height (cm) 
PSB aplication gave no. significant effect on crop height at 14 DAP, 18 DAP, and 42 DAP. Its influence showed at 56 DAP. Increasing crop height at 56 DAP related with role of PSB that can released $\mathrm{P}$ total from sand pit soil became P-available in the soil so the crop absorbed it for vegetative development. .PSB increase the available P content in soils [10] and stimulate crop height [11] [12]. The increase of plant growth parameters inoculated with PSB could be attributed to a greater absorption of nutrients, especially $\mathrm{P}$ [13],P is needed for root development. Developed root would absorp nutrients and water from soil bigger including nitrogen wich is needed for crop height development.

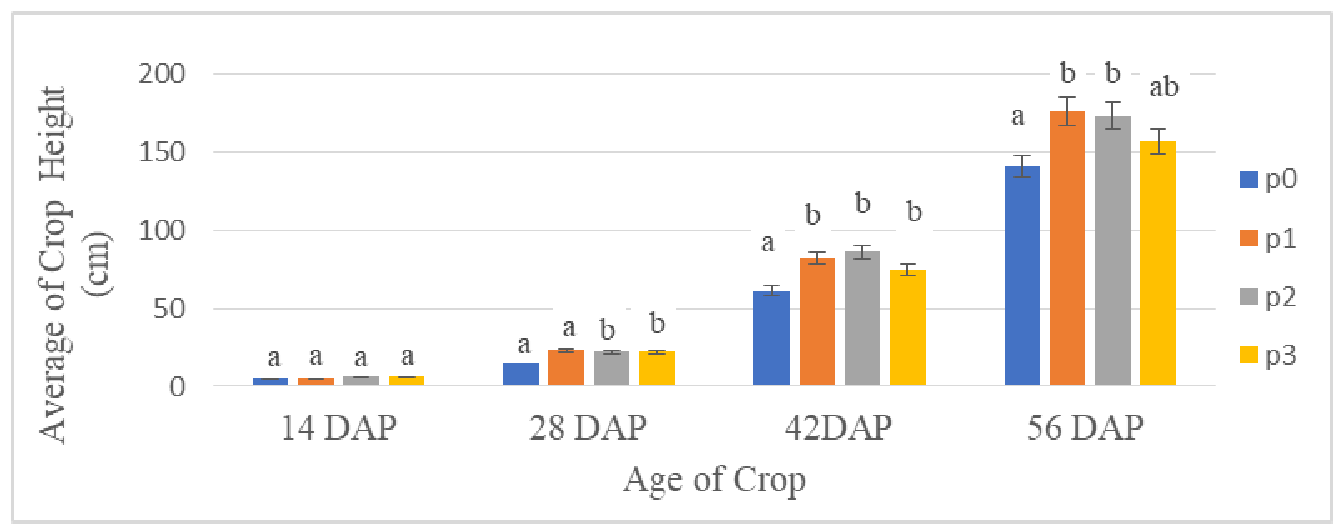

Figure 2. The Effect of Bokhasi Type on Average of Crop Height $(\mathrm{cm})$

Bokhasi application showed significant effect earlier. Bokhasi of I. cylindrica and E. crassipes inreased crop height starting from 28 DAP and continued untill 56 DAP. Bokhasi of T. diversifolia reached same influence with the others weed bokhasi from 42 DAP. Data from Figure 2 can be concluded that all weed bokhasi are slow release. These organic material need time to decompose its nutrients. After nutrients decomposed corn crop used its nitrogen for crop height development [10]. T. diversifolia has $\mathrm{N}$ total 2,23\%, I. cylindrica bohasi 1,59\%, and E. crassipes $0,99 \%$. The lowest $\mathrm{N}$ total of E. crassipes bokhasi caused lower crop height than the others weed bokhasi.

\section{Shoot Root Rasio}

There was no interaction effect of PSB and bokhasi on shoot root rasio. Application of different type of bokhasi increased shoot root rasio significantly, while PSB inoculation showed did not effect on shoot root rasio (Figure 3).

Data from Figure 3 showed that application of bokhasi type increased shoot root rasio. Among bokhasi type namely Tithonia diversifolia, Imperata cylindrica, Eichornia crassipes showed the same influence on shoot root rasio. It is mean that Tithonia diversifolia, Imperata cylindrica, Eichornia crassipes can be used as source of organic matter especially in order to stimulate photosynthate partition to shoot part as indicated by more than one shoot root rasio value. 


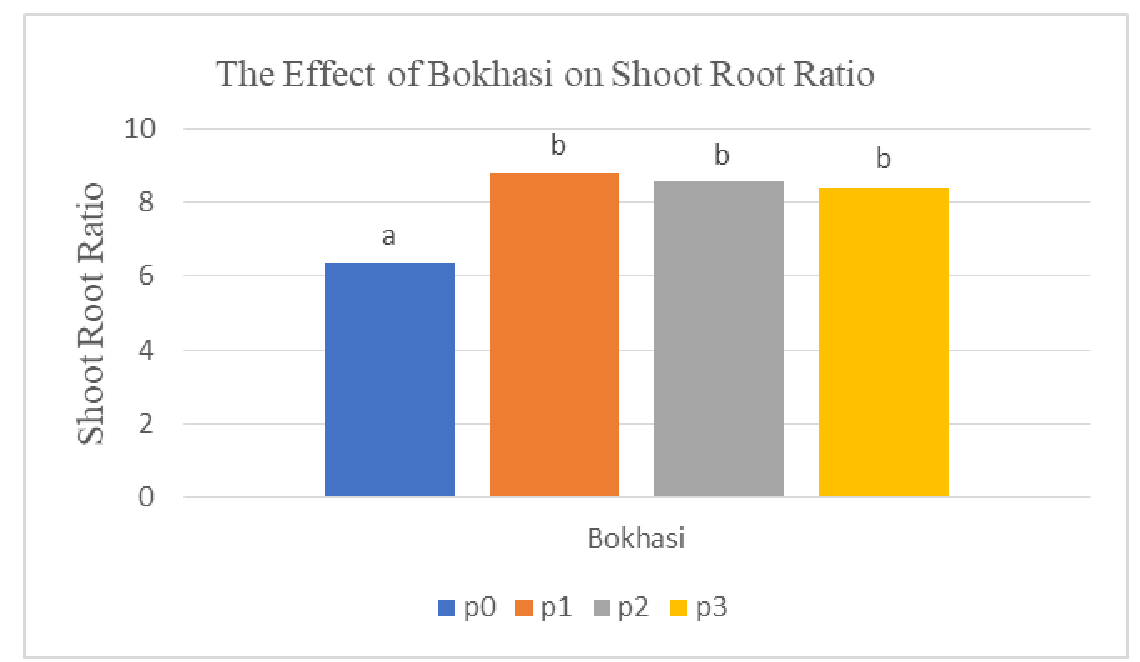

Figure 3. The Effect of Bokhasi on Shoot Root Ratio

\section{Harvest Index}

Application PSB and bokhasi showed interaction effect on harvest index. The highest harvest index showed by application PSB with out application of bokhasi (Figure 4). PSB had the maximum stimulatory effect on shoot dry weight [14] as indicated by shoot root ratio value was higher than one (Figure3). Improvement of shoot growth due to proper P supply. As the work PSB increasing P available content in the soil [13]

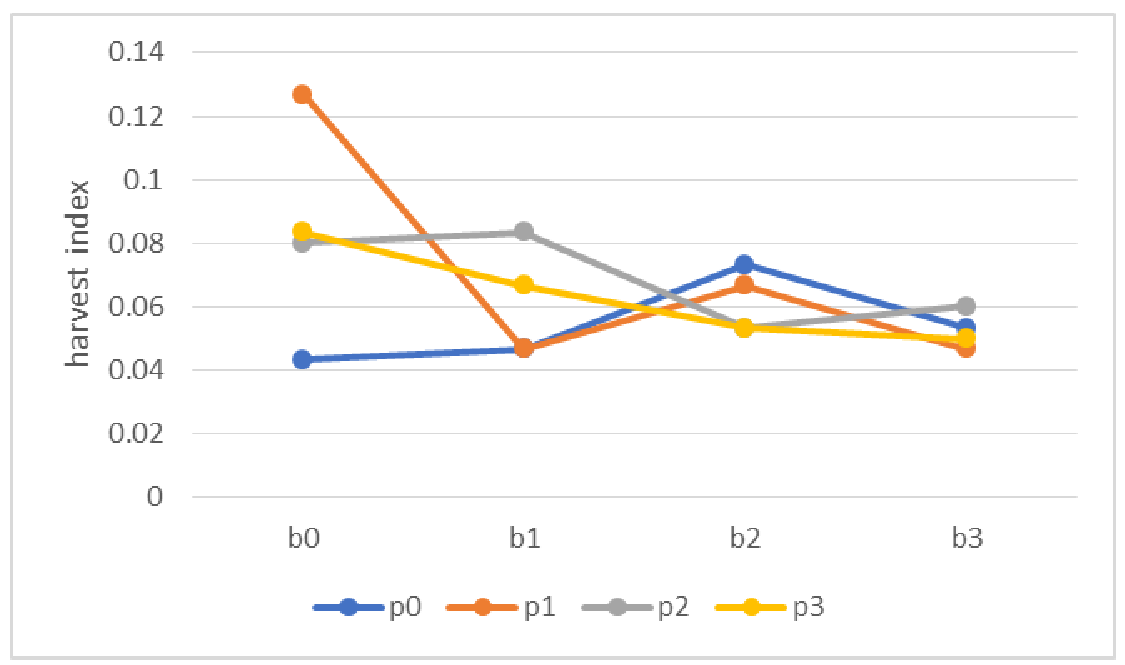

Figure 4. The Effect of PSB and Bokhasi on Harvest Index 


\section{Dry Weight of Cob without Straw (g)}

Application of PSB and Bokhasi had no interaction effect on dry weight cob with out straw. Application PSB had main effect on dry weight of cob with out straw (Figure 5). Application bokhasi also had main effect on dry weight of cob with out straw (Figure 6).

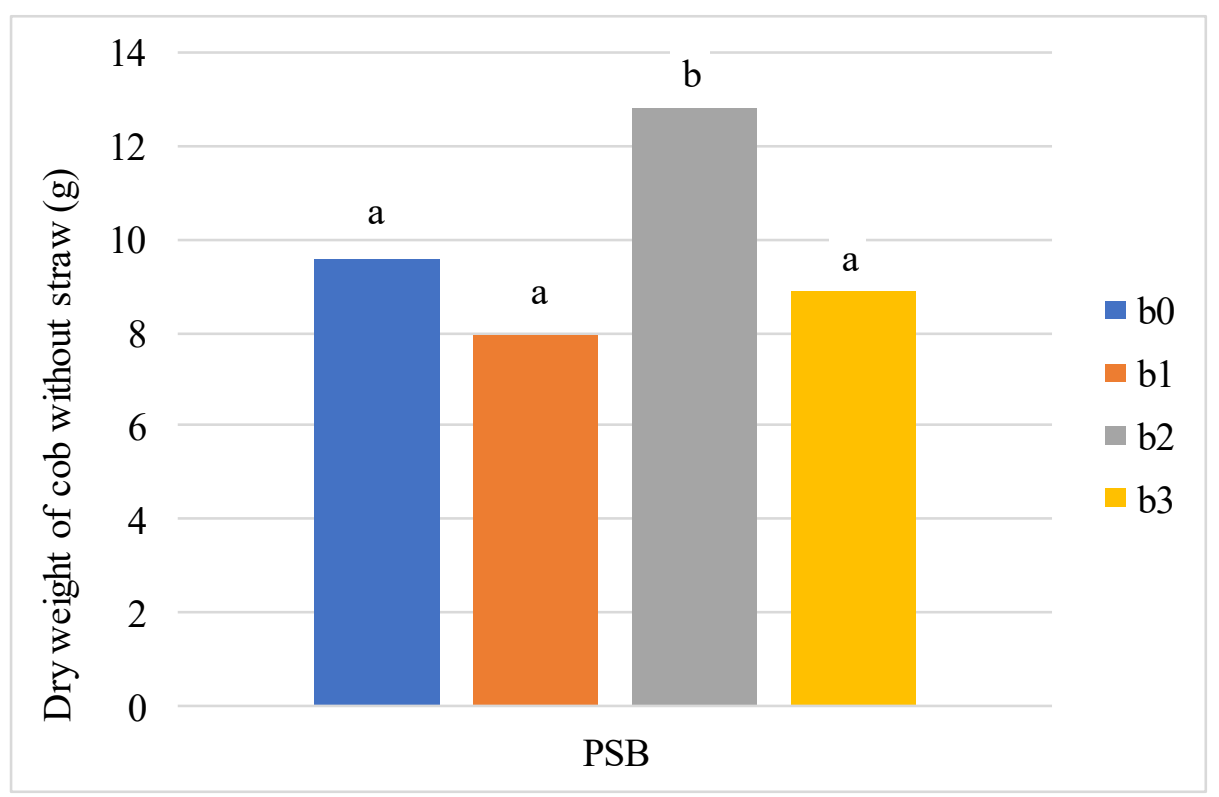

Figure 5. The Effect of PSB on Dry Weight of Cob without Straw (g)

Appalication of PSB $25 \mathrm{ml}$ polybag $^{-1}$ showed the highest dry weight of cob with out straw. Application of PSB $25 \mathrm{ml}$ polybag $^{-1}$ was the most effective dosage. With these dosage PSB is able to release $\mathrm{P}$ total that there are many in the sand pit soil to $\mathrm{P}$ available soil. The PSB released phosphatase enzyme that accelerates the $P$ availability process and increased of pod dry weight [15]. With $\mathrm{P}$ available many in soil then the crops will absorb it to increase and promoted the fruit growth of corn plants. Adding $\mathrm{P}$ in the generative period is allocated to the formation of seeds or fruit crops that accelerates the formation of fruit and seeds and increases production. 


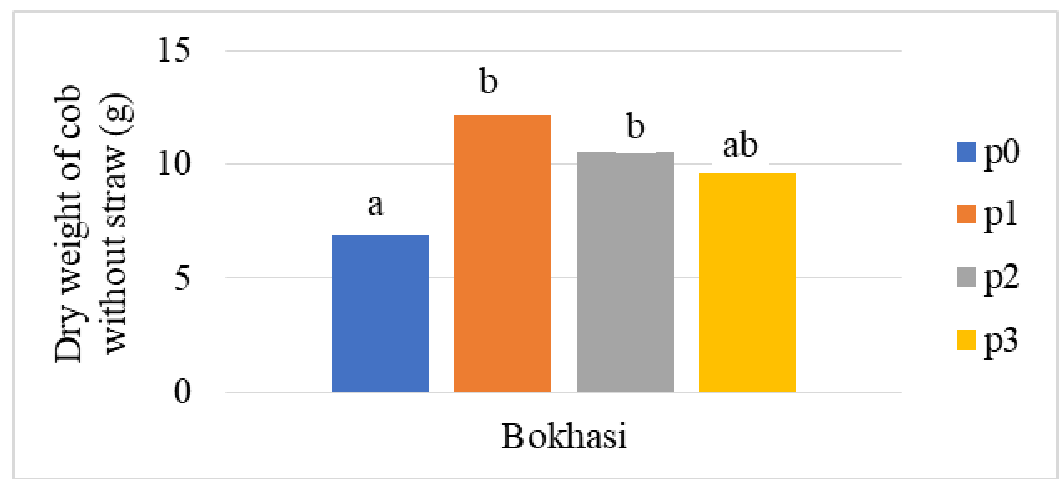

Figure 6. The Effect of Bokhasi on Dry Weight of Cob without Straw (g)

Application of bokhasi type increased dry weight of cob with out straw. Bokhasi of Tithonia diversifolia, Imperata cylindrica showed significantly higher dry weight of cob with out straw than Eichornia crassipes. The first two bokhasi contained higher potasium than $E$. Crassipes. K nutrient is responsible for cob developmnet. Data of high dry weight of cob with out straw also is related to the better vegetative growth by both types of bokhasi as can be seen from data of crop height (Figure 1 and 2).

\section{Wet Weight of Cob without Straw}

Dual application of PSB and weed bokhasi gave no. interaction effect on wet weight of cob without straw. PSB and weed bokhasi showed main effect on wet weight of cob without straw (Figure 7 and 8).

Application PSB increased wet weight of cob without straw when it applied $25 \mathrm{ml}$ polybag $^{-1}$ and $30 \mathrm{ml} \mathrm{polybag}^{-1}$ (Figure 7). Dosage is important its related to the number of colonies of bacteria that can be spread in the media. A dosage of $25 \mathrm{ml}$ was adequate for the amount of the spread of Pseudomonas cepacea in the media, so this bacterium is able to release the $\mathrm{P}$ total in the sand pit soil. The results of the $\mathrm{P}$ un-available released combined with the $\mathrm{P}$ available soils was adequate quantities for the purposes of corn formation. 


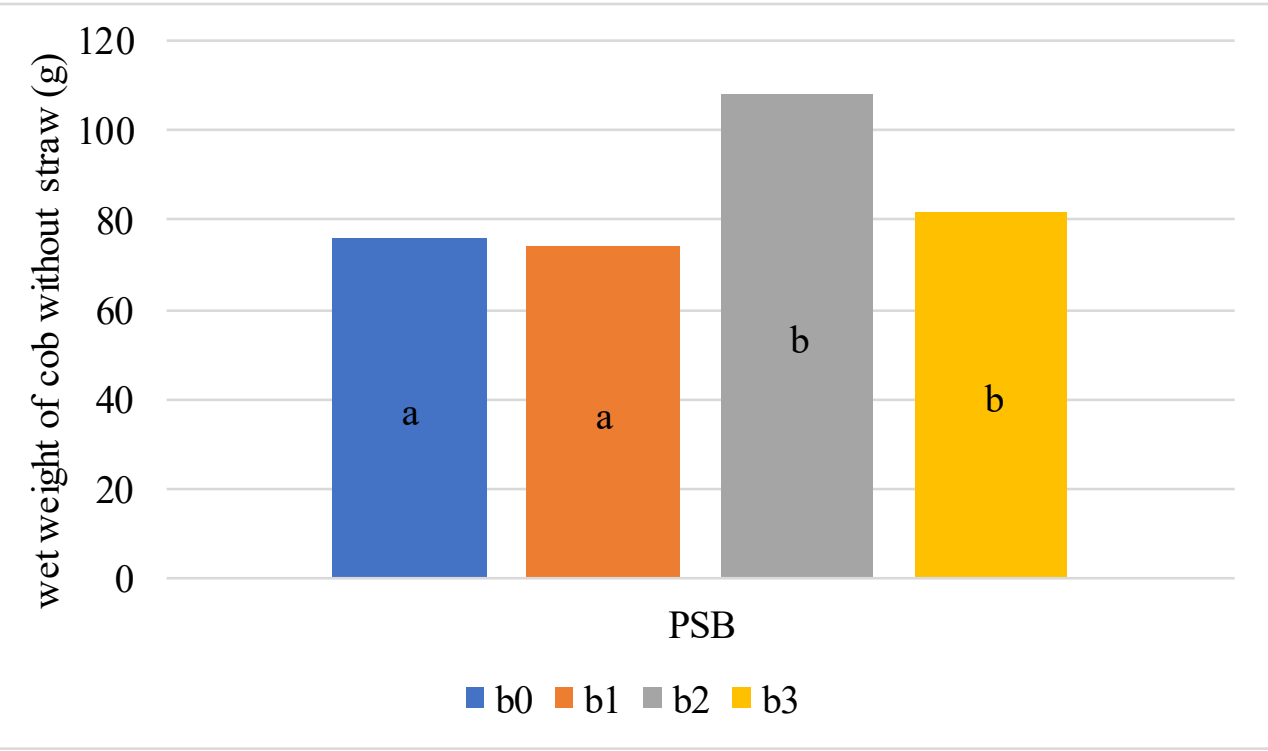

Figure 7. The Effect of PSB on Wet Weight of Cob without Straw (g)

All weed bokhasi was used in this experiment improved wet weight of cob without straw as indicator of crop production (Figure 8). These organic matter provided $\mathrm{P}$ and $\mathrm{K}$ were needed by corn crop yield. Bokhasi of T. diversifolia and I. Cylindrica had higher $\mathrm{P}$ and $\mathrm{K}$ than E. Crassipes. 


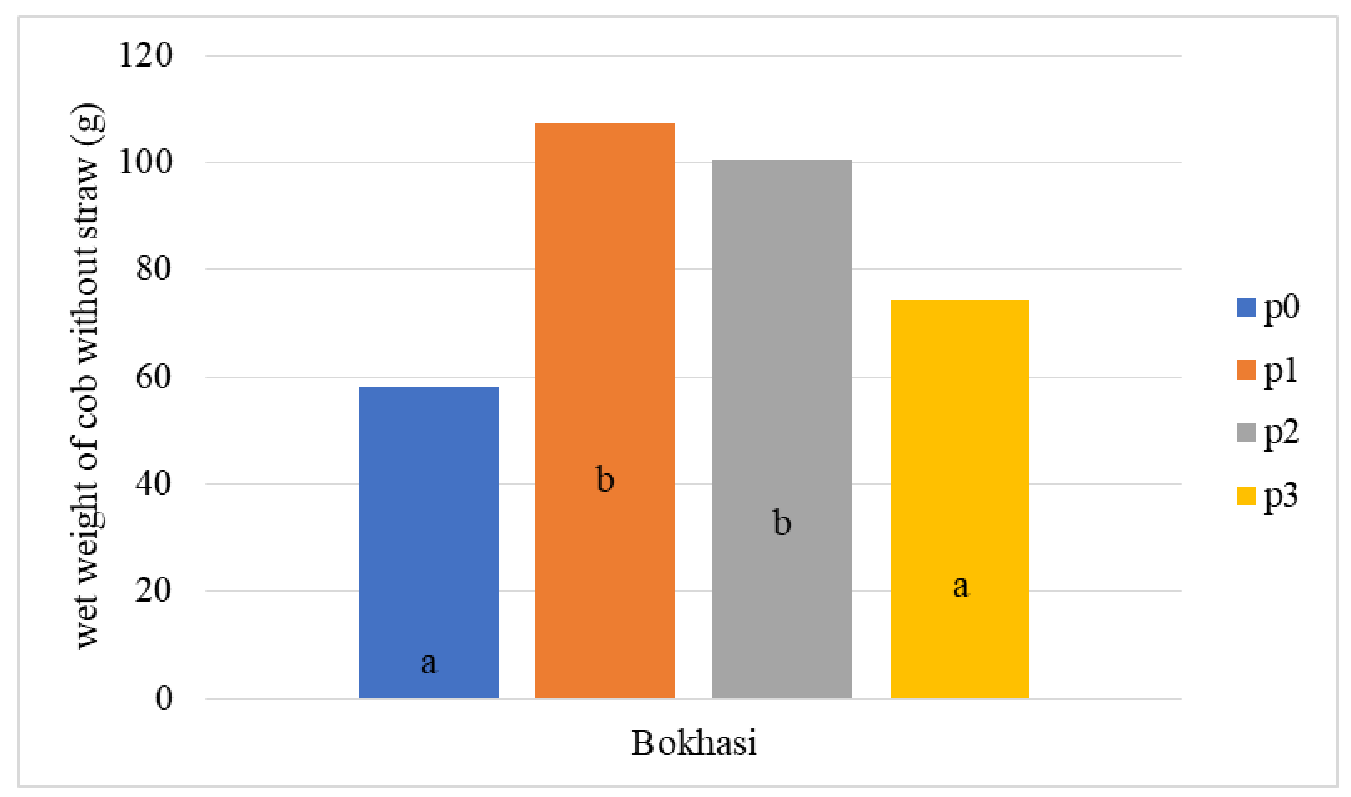

Figure 8. The Effect of Bokhasi on Wet Weight of Cob without Straw (g)

\section{Conclusion}

Application of weed of T. Diversifolia and I. cylindrica promote corn crop growth and crop yield. While application PSB dosage $25 \mathrm{ml} \mathrm{polybag}^{-1}$ increase growth and yield of the corn crop

\section{References}

[1] M. F. Ramadhan, C. Hidayat, and S. Hasani, "Pengaruh Aplikasi Ragam Bahan Organik dan FMA terhadap Pertumbuhan dan Hasil Tanaman Cabai (Capsicum annum L.) Varietas Landung pada Tanah Pasca Galian C," J. Agro, vol. 2, no. 2, pp. 50-57, 2015.

[2] C. Hidayat, Y. Setiati, and P. Gustini, "Growth and yield of chili on post-mine sandpits treated by Arbuscular Micorhizal fungi and organic matter,” IOP Conf. Ser. Mater. Sci. Eng., vol. 434, no. 1, 2018.

[3] C. J. Bronick and R. Lal, "Soil structure and management: A review," Geoderma, vol. 124, no. 1-2, pp. 3-22, 2005.

[4] C. Hidayat, R. Rosdiana, B. Frasetya, and S. Hasani, "Improvement of Physical Properties of Inceptisols and Yield of Sweet Corn Affected by Arbuscular Mycorrhizal Fungi and Manure Applications," KnE Life Sci., vol. 2, no. 6, p. 158, 2017.

[5] I. Celik, I. Ortas, and S. Kilic, "Effects of compost, mycorrhiza, manure and fertilizer on some physical properties of a Chromoxerert soil," Soil Tillage Res., vol. 78, no. 1, pp. 59-67, 2004.

[6] A. Nurbaity, C. Hidayat, D. Hudaya, and J. Sauman, "Mycorrhizal fungi and organic matter affect some physical properties of andisols," Soil water J., vol. 2, no. 2, pp. 639-644, 2013. 
[7] S. Mehrvarz and M.R.Chaichi, "Effects of phosphate solubilizing microorganisms and phosphorus chemical fertilizer on forage and grain quality of barely (Hordeum vulgare L.)," Am. J. Agric. Environ. SciVeterinary J., vol. 3, no. 2, pp. 855-860, 2008.

[8] A. K. Pasha, E. Mulyana, C. Hidayat, M. A. Ramdhani, O. T. Kurahman, and M. Adhipradana, "System Design of Controlling and Monitoring on Aquaponic Based on Internet of Things," in Proceeding of 2018 4th International Conference on Wireless and Telematics, ICWT 2018, 2018.

[9] A. Kkan et al., "Phosphorus Solubilizing Bacteria: Occurrence, Mechanisms and their Role in Crop Production," J Agric Biol Sci, vol. 1, 2009.

[10] M. Tahir et al., "Combined application of bio-organic phosphate and phosphorus solubilizing bacteria (Bacillus strain MWT 14) improve the performance of bread wheat with low fertilizer input under an arid climate," Brazilian J. Microbiol., vol. 49, pp. 15-24, 2018.

[11] M. Liu et al., "Selection and evaluation of phosphate-solubilizing bacteria from grapevine rhizospheres for use as biofertilizers," Spanish J. Agric. Res., vol. 14, no. 4, 2016.

[12] J. Panhwar, Q. A., Radziah, O., Naher, U. A. and Shamshuddin, " Effect of phosphatesolubilizing bacteria and organic acid on P solubilization from phosphate rock in aerobic ric," Sustain World J., vol. doi, p. 10.1155/2013/272409, 2013.

[13] B. Charana Walpola and M. H. Yoon, "Phosphate solubilizing bacteria: Assessment of their effect on growth promotion and phosphorous uptake of mung bean (Vigna radiata [L.] R. Wilczek)," Chil. J. Agric. Res., vol. 73, no. 3, pp. 275-281, 2013.

[14] T. N. El Sebai, B. A. Bakry, M. M. A. Allah, and H. M. S. El-bassiouny, "Physiological Effect of Bio - stimulant ( Phosphate solubilizing bacteria ) on growth and yield of two flax phosphate," 2019. [15] C. Hidayat, B. Frasetya, and I. N. Syamsudin, "Adjustment of phosphorus concentration to increase growth and yield of cherry tomato using hydroponic drip system," J. Agro, vol. 5, no. 2, pp. $140-147,2018$. 